which clinically bear some resemblance to those of cowpox. Orf produces lesions in the mouths of sheep and is mainly seen as an infection of lambs. The third paravaccinia virusbovine papular stomatitis virus-is now thought to be the same virus as that causing milker's nodules. ${ }^{8}$ Bovine papular stomatitis has recently been reported in Britain ${ }^{8}$ and causes lesions which are clinically similar to milker's nodules on the hands and forearms of human handlers. ${ }^{81011}$

Human infection with the paravaccinia viruses of orf and milker's nodules is not uncommon in rural areas. Infection is seen in people who have contact with cows or sheep or with products derived from them. For example, orf is seen in shepherds, butchers, sheep shearers, and veterinary surgeons and has been described in housewives with a liking for sheep's heads. ${ }^{12-19}$ Milker's nodules are also seen in veterinary surgeons and in farm workers who tend dairy cattle-even if the animals are milked by machine. ${ }^{52021}$ Both viruses cause similar disease in man, and the name ascribed to the infection depends on the animals which were the probable source of infection. $^{20}$ As a result, orf is diagnosed in shepherds and milker's nodules in cowmen. Clinically the lesions are usually single, but cases with two or with multiple lesions have been reported. The fingers and hands are the commonest sites for them, but lesions have been described on the arms, face, neck, and occasionally on the leg. Different types of lesion may be seen. Most start as bluish-red papules or nodules, which are sometimes surmounted by a small white blister. Ulceration is common. Lesions may also take the form of granulomas in which there is ulceration with proliferation of grey-coloured epidermal tissue. Many appear to be vesicular, but it is often difficult to extract fluid from them. ${ }^{22}$ The most striking feature is that the lesions are painless, though they look like acute inflammatory reactions. There is usually no constitutional disturbance. Lymphangitis and lymphadenitis have been described, but-in contrast to human cowpox-appear to be rare. The lesions persist for about five to eight weeks and resolve spontaneously without treatment. One attack appears to confer long-lasting immunity against reinfection, but, unlike cowpox, there is no cross-immunity with vaccinia. ${ }^{22} 23$

The relationship between the three paravaccinia viruses is obscure, though it is clear that they are closely related. J. Nagington and his co-workers have shown that orf and

\footnotetext{
Jenner, E., An Inquiry into the Causes and Effects of the Variolae Vaccinae. 1798. London.

- Downie, A. W., Brit. med. F., 1951, 2, 251.

Reece, R. J., Proc. roy. Soc. Med., 1922, 15, 13. Section of Epidemiology and State Medicine.

- McMath, W. F. T., and Wilson, H. T. H., Brit. med. F., 1965, 1, 1041 .

Nomland, R., and McKee, A. P., Arch. Derm. Syph. (Chic.), 1952, 62, 663 .

- Peters, D., Müller, G., and Büttner, D., Virology, 1964, 23, 609.

Nagington, J., Plowright, W., and Horne, R. W., ibid., 1962, 17, 361

Nagington, J., Plowright, W., and Horne, R. W., ibid., 1962, 17,

- Williams, D. R., Plowright, W., and Burrows, R., ibid., 1966, 78, 571

- Williams, D. R., Plowright, W., and Burrows, R., ibid., 1966, 78, 571.

1 Carson, V. M. D., and Kerr, K. M., ibid., 1967, 151, 183.

Peterkin, G. A. G., Brit. F. Derm. Syph., 1937, 49, 492.

Blakemore, F., Abdussalam, M., and Goldsmith, W. N., ibid., 1948 $60,404$.

Lyell, A., and Miles, J. A. R., Brit. med. F., 1950, 2, 1119.

5 Rankin, A. K., ibid., 1950, 2, 1279.

Kewish, O. K., ibid., 1951, 1, 356.

Peterkin, G. A. G., ibid., 1951, 1, 588.

Hodgson-Jones, I. S., ibid., 1951, 1, 795.

- Lloyd, G. M., ibid., 1951, 1, 1144 .

to Nagington, J., Tee, G. H., and Smith, J. S., Nature (Lond.), 1965, 208, 505.

1 Neale, E. J. E., and Calvert, H. T., Brit. F. Derm., 1967, 79, 318.

Blank, H., and Râke, G., Viral and Rickettsial Diseases of the Skin Eye and Mucous Membranes of Man, pp. 193-202, 1955. London.

is Nagington, J., and Whittle, C. H., Brit. med. Y., 1961, 2, 1324.

" Lauder, I. M., Martin, B., Martin,'W. B., and Nagington, J., Vet. Rec., $1966,78,926$.
}

milker's nodules viruses are similar in their morphology and cultural characteristics. ${ }^{20}$ In addition I. M. Lauder and his colleagues have shown that the bovine virus of milker's nodules can produce lesions in lambs after inoculation on to the gums and lips. ${ }^{21}$

Neither cowpox nor paravaccinia is a serious infection in man. Diagnosis will present few problems to general practitioners in rural areas or to dermatologists, who also see these diseases from time to time. However, the infections might well puzzle a newly qualified casualty officer in a city, who may come across lesions on the hands of butchers, slaughtermen, or veterinary surgeons. When the infection has been diagnosed, the patient can be reassured-firstly as to the nature of the lesion, and secondly that it will resolve spontaneously and without complications within the following month or two.

\section{Pseudomonas Infection in Hospital}

In the last few years the problems of staphylococcal crossinfection seem to have become more manageable, thanks especially to the semisynthetic penicillins tolerant of penicillinase. Unfortunately the same cannot be said of infection with Pseudomonas aeruginosa (pyocyanea). Indeed, reports of such infections have become more frequent. This can be partly explained by the relative ineffectiveness of chemotherapy for pseudomonas infection. Successful treatment of infections with Gram-positive cocci has undoubtedly brought the less tractable infections with Gram-negative bacilli such as Ps. aeruginosa into prominence. A relative and absolute increase in the amount of infection by these opportunists appears to have occurred. ${ }^{1-3}$

Epidemiological features of pseudomonas infection which have made it hard to eradicate 4 include its tendency to grow or at least survive in moist environments and its relative insensitivity to certain disinfectants as well as to most antibiotics. Moreover, despite a low pathogenicity for healthy people, it tends to be more pathogenic and invasive than most other common bacteria in patients or in tissues with low humoral resistance-for example, in infants and in leukaemic patients, in the chambers of the eye, and on the meninges. Not surprisingly, Ps. aeruginosa is a special hazard to patients treated with corticosteroids and with immunosuppressive drugs. $^{3-5}$ In burned patients two factors encourage pseudomonas infection-the presence of moist slough, which is easily colonized by $P$ s. aeruginosa, and (when the burns are extensive) reduced resistance to invasion.

The sources of these infections are varied and often elusive. Unlike Escherichia coli and Staphylococcus aureus, Ps. aeruginosa is usually not carried in large numbers by healthy people. Recent studies $^{6}$ have shown a larger proportion (about $12 \%$ ) of healthy people to be carrying Ps. aeruginosa, at least in small numbers, than most previous surveys had suggested, and in another recent report ${ }^{7}$ about $5 \%$ of healthy people were found to carry Ps. aeruginosa in the saliva. But, while sporadic self-infection with Ps. aeruginosa can undoubtedly occur, most endemic infection such as in burns and all outbreaks can be attributed to contamination from another human source or the inanimate environment. In many cases the source has been traced by typing of strains. ${ }^{6-10}$ Human sources are generally sites of heavy infectionwounds, burns, the urinary tract. Established inanimate 
sources include saline, ${ }^{11}$ soap and antiseptic solutions, ${ }^{12}$ eyedrops, ${ }^{13}$ creams, ${ }^{14}$ jellies, ${ }^{15}$ and equipment which contains standing water or retains moisture (especially respirators and resuscitation equipment for premature infants), ${ }^{15-17}$ moist brushes (for example, shaving-brushes used for depilation of the scalp before craniotomy), ${ }^{18}$ and surgical instruments and catheters "sterilized" with an inadequate disinfectant. ${ }^{1920}$ Dry sources (dust, air) are uncommon but may on occasion be important. ${ }^{21}$ The hands of nurses in wards where the infection occurs are often found to carry Ps. aeruginosa and are likely to contaminate uninfected patients if the nurses do not wear rubber or plastic gloves when attending to them. ${ }^{22}$ The importance of some sites which are commonly contaminated-for example, sinks and drains-has not been clearly established.

At page 313 of the B.M.7. this week Dr. J. E. Tinne, Dr. A. M. Gordon, Mr. W. H. Bain, and Mr. W. A. Mackey report an outbreak of infection of the respiratory tract with Ps. aeruginosa in a cardiac surgery unit. During two months, in which 30 operations were performed, five patients became infected with this organism and three of them died. These deaths occurred in the eight patients of the series who had open heart surgery followed by tracheostomy, hydrocortisone therapy, broad-spectrum antibiotics, and prolonged mechanical ventilation. All strains were of the infrequent pyocine type 10. A strain of the same type was found in the connecting tube of a respiratory ventilator and in a rebreathing bag. These findings strongly suggest that infection was acquired by the patient's respiratory tract from the ventilator. The authors subsequently found $P s$. aeruginosa on various fittings and pieces of equipment in the operating-theatre suite, and introduced measures to prevent recurrences. These included the use of a new disinfectant, which appeared to be effective in removing $P$ s. aeruginosa from contaminated objects and sites.

Yow, E. M., 7. Amer. med. Ass., 1952, 149, 1184

Forkner, C. E., Frei, E., Edgcomb, J. H., and Utz, J. P., Amer. F. Med., 1958, 25, 877.

Finland, M., New Engl. 7. Med., 1960, 263, 207.

Brit. med. f., 1964, 2, 1019.

Margaretten, "W., Nakai, H., and Landing, B. H., New Engl. 7. Med., 1961, 265, 773.

Shooter, R. A., et al., Lancet, 1966, 2, 1331

Sutter, V. L., Hurst, V., and Landucci, A. O. J., F. dent. Res., 1966, 45,1800 .

- Wahba, A. H., Brit. med. f., 1965, 1, 86.

Gillies, R. R., and Govan, J. R W., F. Path. Bact., 1966, 91, 339.

Sutter, V. L., Hurst, V., and Fennell, J., Health Lab. Sci., 1965, 2, 7

Ayliffe, G. A. J., Barry, D. R., Lowbury, E. J. L., Roper-Hall, M. J., and Walker, W. M., Lancet, 1966, 1, 1113.

Lowbury, E. J. L., Brit. F. industr. Med., 1951, 8, 22

Ridley, F., Brit. F. Ophthal., 1958, 42, 641.

Noble, W. C., and Savin, J. A., Lancet, 1966, 1, 347.

Phillips, I., ibid., 1966, 1, 903.

Bassett, D. C. J., Thompson, S. A. S., and Page, B., ibid., 1965, 1, 781

Rubbo, S. D., Gardner, J. F., and Franklin, J. C., F. Hyg. (Lond.) $1966,64,121$

Ayliffe, G. A. J., Lowbury, E. J. L., Hamilton, J. G., Small, J. M., Asheshov, E. A., and Parker, M. T., Lancet, 1965, 2, 365.

Rogers, K.' B., f. appl. Bact., 1960, 23, 533.

Moore, B., and Forman, A., Lancet, 1966, 2, 929.

Moore, B., and Forman, A., Lancet, 1966

Lowbury, E. J. L., ibid., 1954, 1, 292.

Moyer, C. A., Brentano, L., Gravens, D. L.,
Monafo, W. W., Arch. Surg., 1965, 90, 812 .

Cason, J. S., Jackson, D. McG., Lowbury, E. J. L., and Ricketts, C. R. Brit. med Y., 1966, 2, 1288.

Weinstein, M. J., Lucdemann, G. M., Oden, E. M., and Wagman, G. H., Antimicrob. Agents Chemother., 1963, 1.

Bulger, R. J., Sidell, S., and Kirby, W. M. M., Ann. intern. Med., 1963, 59, 593.

Knudsen, E. T., Rolinson, G. N., and Sutherland, R., Brit. med. f., $1967,3,75$.

Brumfitt, W., Percival, A., and Leigh, D. A., Lancet, 1967, 1, 1289

¿9 Brumfitt, W., Percival, A., and Leigh, D. A., Lancet, 1967, 1,

" Jones, R. J., and Lowbury, E. J. L., Brit. med. F., 1967, 3, 79. Wallace and A. W. Wilkinson, Edinburgh, p. 470 . Burns,

"Jones, R. J., Jackson, D. McG., and Lowbury, E. J. L., Brit. F. plast. Surg., $1966,19,43$
Though outbreaks of Ps. aeruginosa infection continue to be reported, they are often due to some deficiency or error in technique (especially in sterilization or maintenance of sterility) which can be corrected. But outstanding difficulties still exist with types of equipment-for example, mechanical ventilators-that cannot be sterilized by heat, and also with the elaborate nursing procedures of intensive-care units. The design of some types of equipment needs improvement to facilitate cleaning and disinfection. In the treatment of burns the control of Ps. aeruginosa infection has been greatly helped by local application of $0.5 \%$ silver nitrate solution, ${ }^{23}{ }^{24}$ and this can probably be enhanced by modern aseptic methods, notably the use of "isolaters" chambers. Two new antibiotics, gentamicin ${ }^{25} 26$ and carbenicillin, ${ }^{27-29}$ give promise of providing better control of $P s$. aeruginosa infection than has been obtained with the polymyxins, and immunological methods of protection have also shown promise. ${ }^{30} 31$ For the protection of high-risk patients it is desirable to use these and other methods in a system of multiple defences. But no set of rules can succeed without a high standard of aseptic discipline and understanding among the hospital staff under the guidance of an active infectioncontrol officer.

\section{Body Building by Drugs}

The self-administration of anabolic steroids is becoming a problem in athletics. A letter from Dr. D. E. Pearsons at page 353 draws attention to the matter. Taking these artificial aids to athletic performance must surely be condemned as unethical. In addition, it is possibly hazardous to health, for this group of drugs have side-effects.

Those anabolic steroids that are active when taken by mouth commonly affect conventional liver-function tests and occasionally cause jaundice. These side-effects are probably caused by interference with the transport of conjugated compounds into the bile and usually disappear quickly on withdrawal of the drug. Serum enzyme levels of the transaminases S.G.O.T. and S.G.P.T. and lactic dehydrogenase are often raised, though this does not necessarily imply damage to liver cells. Only the compounds active by mouth cause liver damage, because of their particular chemical configuration. They may also raise the level of serum lipids, especially of cholesterol, with the possibility of causing serious harm in that way. This action has been specially noted in two groups of patients-those receiving glucocorticoids and obese diabetics not requiring insulin. ${ }^{1}$ Some anabolic steroids may impair the hepatic degradation of cortisol, enhancing the action of this drug and necessitating a reduction in dosage. ${ }^{23}$

All anabolic steroids so far investigated have proved to have some androgenic activity. In women this may lead to hirsuties, acne, and virilization of the voice. ${ }^{4}$ The patient feels her voice to be strange and is unsure about its use ; in severe cases it wavers between the chest and falsetto registers This effect is irreversible.

Increased muscular development and improved athletic performance are widely believed to result from use of anabolic

\footnotetext{
1 Wynn, B., in Modern Trends in Endocrinology, ed. H. Gardiner-Hill, p. 245. 1967. London.

'James, V. H. T., London, J., and Wynn, V., F. Endocr., 1962, 25, 211

- 1 ibid., 1964, 29, 2.

- Damsté, P. H., Folia phoniat. (Basel), 1964, 16, 10.

s Brit. med. F., 1967, 1, 185.

- Fowler, W. M., jun., Gardner, G. W., and Egstrom, G. H., f. appl. Physiol., 1965, 20, 1038.

Holvey, D. N., Cutler, R. E., and Dowling, J. T., Metabolism, 1965, 14,891 .
} 